\title{
EKSTRAKSI MINYAK DAN RESIN NYAMPLUNG DENGAN CAMPURAN PELARUT HEKSAN-ETANOL
}

\section{SOLVENT EXTRACTION OF CALOPHYLUM OIL AND RESINUSING HEXANE-ETHANOL MIXTURE}

\author{
Ika Amalia Kartika ${ }^{1 *}$, Desita Dwi Kurnia Sari ${ }^{1)}$, Auradelia Febriani Pahan'1), Ono Suparno ${ }^{1)}$, Danu Ariono ${ }^{2)}$ \\ ${ }^{1)}$ Departemen Teknologi Industri Pertanian, Fakultas Teknologi Pertanian, Institut Pertanian Bogor \\ Kampus IPB Dramaga P.O. Box 220, Bogor 16002, Indonesia \\ Email: ikatk@yahoo.com \\ ${ }^{2)}$ Program Studi Teknik Kimia, Fakultas Teknik Industri, Institut Teknologi Bandung, Indonesia \\ Makalah: Diterima 3 Maret 2017; Diperbaiki 20 Juli 2017; Disetujui 31 Juli 2017
}

\begin{abstract}
Calophyllum seeds are potential to be used as raw material for vegetable oil production due to their high oil content $(75.1 \% \mathrm{db})$. In addition, Calophyllum seeds contain resin consistingbeneficial phenolic compounds for health. In this study, Calophyllum seeds were extracted using hexane-ethanol mixture to investigate oil and resin yields and their physicochemical properties, and to obtain the best process condition in oil and resin production from Calophyllum seeds. Experiment was carried out using randomized complete design with threefactors, i.e. extraction times $(5-7 \mathrm{~h})$, temperatures $\left(40-50^{\circ} \mathrm{C}\right)$, and hexane to ethanol ratios $(2: 4,3: 3$ and 4:2). The result of variance analysis showed that extraction time and hexane to ethanol ratio affected significantly on oil and resin yields, density, acid and iod values, whereas temperature influenced only on oil yield, density and acid value. Best oil (58.2\%) and resin (16.2\%) yields were respectively obtained at $5 h$ extraction time, $50^{\circ} \mathrm{C}$ temperature and $4: 2$ hexane to ethanol ratio, and 5hextraction time, $40^{\circ} \mathrm{C}$ temperature and 2:4 hexane to ethanol ratio. At these optimum conditions, the oil had acid value of $14.89 \mathrm{mg} \mathrm{KOH} / \mathrm{g}$, iodine value of $60.75 \mathrm{~g}$ iodine $/ 100 \mathrm{~g}$, viscosity $\left(25^{\circ} \mathrm{C}\right)$ of $71.46 \mathrm{mPa} . \mathrm{s}$, and density $\left(25^{\circ} \mathrm{C}\right)$ of $0.86 \mathrm{~g} / \mathrm{cm}^{3}$. On the other hand, the resin had acid value of $133.76 \mathrm{mg} \mathrm{KOH} / \mathrm{g}$.
\end{abstract}

Keywords: Calophyllum, extraction, ethanol, hexane, oil, resin

\begin{abstract}
ABSTRAK
Biji nyamplung sangat potensial untuk dimanfaatkan sebagai bahan baku minyak nabati karena kadar minyaknya yang tinggi, yaitu dapat mencapai $75,1 \%$ (bk). Biji nyamplung juga mengandung resin dengan kandungan senyawa-senyawa fenolik yang bermanfaat untuk kesehatan. Pada penelitian ini biji nyamplung diekstraksi dengan campuran pelarut heksan dan etanol untuk mengetahui rendemen dan sifat fisikokimia minyak dan resin nyamplung yang dihasilkan, serta untuk mendapatkan kombinasi perlakuan yang menghasilkan minyak dan resin nyamplung dengan rendemen dan kualitas terbaik. Penelitian ini dirancang menggunakan acak lengkap yang disusun secara faktorial dengan faktor waktu ekstraksi $(5-7 \mathrm{jam})$, suhu $\left(40-50^{\circ} \mathrm{C}\right)$ dan nisbah heksan/etanol (2:4, 3:3, 4:2). Hasil analisis keragaman menunjukkan waktu ekstraksi dan nisbah heksan/etanol mempengaruhi rendemen minyak dan resin, densitas, bilangan asam dan iod yang dihasilkan, sedangkan suhu hanya mempengaruhi rendemen minyak, densitas dan bilangan asam. Perlakuan yang menghasilkan rendemen minyak terbaik $(58,2 \%)$ adalah waktu ekstraksi 5 jam, suhu $50^{\circ} \mathrm{C}$ dan nisbah heksan/etanol $4: 2$, sedangkan yang menghasilkan rendemen resin terbaik $(16,2 \%)$ adalah waktu ekstraksi $5 \mathrm{jam}$, suhu $40^{\circ} \mathrm{C}$ dan nisbah heksan/etanol 2:4. Minyak nyamplung hasil perlakuan tersebut mempunyai bilangan asam $14,89 \mathrm{mg} \mathrm{KOH} / \mathrm{g}$, bilangan iod $60,75 \mathrm{~g}$ iod $/ 100 \mathrm{~g}$, viskositas $\left(25^{\circ} \mathrm{C}\right) 71,46 \mathrm{mPa} . \mathrm{s}$ dan densitas $\left(25^{\circ} \mathrm{C}\right) 0,86 \mathrm{~g} / \mathrm{cm}^{3}$, sedangkan resin nyamplung mempunyai bilangan asam $133,76 \mathrm{mg} \mathrm{KOH} / \mathrm{g}$.
\end{abstract}

Kata kunci: ekstraksi, etanol,heksan, minyak, nyamplung, resin

\section{PENDAHULUAN}

Nyamplung (Calophyllum inophyllum) adalah salah satu jenis tanaman yang tumbuh di daerah berpasir seperti di tepi sungai atau pesisir pantai sampai ketinggian $200 \mathrm{dpl}$. Tanaman ini sering disebut sebagai bintangur atau kapur naga, dan tergolong dalam kerajaan Plantae, divisi Spermatophyta, subdivisi Angiospermae, kelas Dicotyledone, bangsa Guttiferales, keluarga Calophyllaceae, genus Calophyllum, dan spesies
Calophyllum inophyllum L. (Heyne, 1987). Tanaman nyamplung tersebar secara luas di dunia, yaitu di Madagaskar, Afrika Timur, Asia Selatan, Asia Tenggara, Kepulauan Pasifik, Hindia Barat dan Amerika Serikat (Atabani dan Cesar, 2014). Di Indonesia tanaman ini tersebar luas di pulau Jawa, Sumatera, Bali, Nusa Tenggara, Maluku, Sulawesi dan Papua (Bustomi et al., 2008). Tanaman nyamplung sejak lama dimanfaatkan untuk berbagai keperluan, kayunya untuk membuat perahu dan buahnya untuk mempoduksi minyak nabati. Kayu 
tanaman nyamplung terkenal sangat kuat dan buahnya menghasilkan biji yang mengandung minyak dengan kadar yang tinggi (40-73\%) (Syakir dan Karmawati, 2013).

Minyak yang dihasilkan dari biji nyamplung bersifat toksik karena biji nyamplung mengandung zat seperti damar yang beracun (resin), dan zat tersebut terdeteksi mengandung senyawasenyawa ester asam fitalat (Taifan et al., 2013; Anggraini et al., 2014), inofilum A-E, kalofiloid, asam kalofinat (Dweck dan Meadows, 2002), dan polimer proantisoanidin (Tempesta, 1993). Selain itu minyak nyamplung mengandung senyawa-senyawa seperti keton xanton, coumarin, flavonoid, triterpen, asam begonia, serta senyawa-senyawa fenolik dan polifenolik seperti calophyllolide yang bermanfaat sebagai antioksidan (Liu et al., 2015). Oleh karena itu, minyak nyamplung banyak dimanfaatkan untuk keperluan non pangan, farmasi dan kosmetika seperti untuk pelitur, pelapis, minyak rambut, minyak urut, sabun (Atabani dan Cesar, 2014) dan biodiesel (Dalvi et al., 2012; Chavan et al., 2013; Leksono et al., 2014; Muhammad et al., 2014; Ong et al., 2014; Silitonga et al., 2014).

Ekstraksi minyak nyamplung hingga saat ini dilakukan melalui 3 tahapan proses yang terpisah, yaitu persiapan bahan baku, ekstraksi dan pemurnian minyak (Syakir dan Karnawati, 2013). Proses persiapan bahan baku meliputi pengupasan, perajangan, pengeringan, penumbukan dan pengukusan. Proses ekstraksi dilakukan dengan pengepresan menggunakan mesin ulir (screw press, expeller press), dan proses pemurnian (degumming) dengan penambahan asam fosfat (Kartika et al., 2010). Proses ini hanya dapat mengekstraksi 30-50\% minyak dari biji dengan mutu minyak yang rendah. Minyak berwarna coklat kehijauan dan sangat kental. Selain itu, minyak memiliki kandungan resin yang tinggi, sehingga bilangan asamnya tinggi (54,18-59,95 mg KOH/g).

Kenyataan tersebut menunjukkan perlunya cara untuk memperbaiki proses ekstraksi minyak nyamplung, yang dapat menghasilkan minyak dengan bilangan asam yang rendah dan terbebas dari resin. Proses ekstraksi dengan menggunakan 2 jenis pelarut (polar dan non polar) dapat menjadi solusi untuk hal tersebut. Minyak nyamplung merupakan jenis minyak non polar, sehingga minyak nyamplung dapat larut dalam pelarut non polar seperti heksan, eter, kloroform, toluen, dan lain-lain. Di lain pihak, pelarut polar merupakan pelarut yang cocok digunakan untuk mengekstraksi resin (Jos et al., 2011). Dengan demikian penggunaan pelarut polar dan non polar dalam proses ekstraksi minyak nyamplung memungkinkan untuk memisahkan minyak dari resin tanpa harus melakukan proses pemurnian (degumming) dan fraksinasi. Selain itu, dari proses ekstraksi ini juga dapat dihasilkan resin nyamplung.
Studi ekstraksi minyak nyamplung dari campurannya dengan resin menggunakan pelarut non polar (petroleum eter atau heksan) dan polar (metanol) menunjukkan bahwa penggunaan pelarut non polar dan polar dengan perbandingan sebesar $75 \%$ dan $25 \%$ telah menghasilkan rendemen (> 94\%) dan kemurnian (> 71\%) minyak tertinggi (Anggraini et al., 2014). Dari penelitian tersebut dapat diketahui bahwa minyak nyamplung larut dalam pelarut non polar seperti petroleum eter dan heksan, sedangkan resin larut dalam pelarut polar seperti metanol. Selain itu, resin juga larut dalam etanol dan isopropil alkohol, heksan, dan lain-lain (Assagaf et al., 2012).

Selain jenis pelarut, faktor-faktor lainnya yang harus diperhatikan dalam proses ekstraksi minyak adalah persiapan bahan sebelum ekstraksi, ukuran bahan, jumlah pelarut, dan kondisi operasi selama proses ekstraksi berlangsung (Swern, 1982). Assagaf et al. (2012) menambahkan bahwa komposisi pelarut, waktu ekstraksi, suhu dan rasio bahan dengan pelarut merupakan faktor-faktor yang dapat mempengaruhi efisiensi ekstraksi. Berdasarkan hal tersebut, maka perlu dilakukan kajian terhadap proses ekstraksi biji nyamplung untuk mendapatkan rendemen minyak dan resin yang optimal dengan sifat fisikokimia yang baik. Penelitian ini bertujuan untuk menganalisis pengaruh kondisi proses ekstraksi terhadap rendemen dan sifat fisikokimia minyak dan resin nyamplung, serta untuk mendapatkan kombinasi perlakuan yang menghasilkan minyak dan resin nyamplung dengan rendemen dan mutu terbaik.

\section{BAHAN DAN METODE}

\section{Bahan dan Alat}

Bahan yang digunakan dalam penelitian ini adalah buah nyamplung yang diperoleh dari KHDTK Carita, Banten. Bahan kimia yang digunakan adalah larutan $\mathrm{H}_{2} \mathrm{SO}_{4}$ pekat, $\mathrm{H}_{2} \mathrm{SO}_{4} 0,325$ $\mathrm{N}, \mathrm{H}_{2} \mathrm{SO}_{4} 0,02 \mathrm{~N}, \mathrm{NaOH} 6 \mathrm{~N}, \mathrm{NaOH} 1,25 \mathrm{~N}$, katalis $\mathrm{CuSO}_{4}: \mathrm{Na}_{2} \mathrm{SO}_{4}, \mathrm{Na}_{2} \mathrm{~S}_{2} \mathrm{O}_{3} 0,1 \mathrm{~N}$, asam borat $2 \%$, $\mathrm{KOH} 0,1 \mathrm{~N}$, larutan pati $1 \%$, KI $15 \%$, larutan Wijs, kloroform, indikator mensel, indikator PP, heksan, etanol dan akuades. Pelarut dan bahan-bahan kimia yang digunakan adalah teknis dan analytical grade, yang diperoleh dari Sigma-Aldrich dan Brataco, Indonesia. Alat yang digunakan dalam penelitian ini adalah neraca analitik, gelas piala, labu erlenmeyer, labu Kjedhal, kertas saring, plastik, gegep, cawan porselin, cawan aluminium, tanur, oven, labu leher tiga, hot plate stirrer, magnetic bar, blender, pisau, termometer, pendingin balik, piknometer, rheometer dan alat gelas lainnya.

\section{Metode}

Buah nyamplung dikupas menggunakan pisau untuk memisahkan biji dari cangkang, dan selanjutnya biji dikeringkan pada suhu $50-70^{\circ} \mathrm{C}$ 
selama 48-72 jam untuk menurunkan kadar airnya hingga $\pm 2 \%$. Pengeringan dilakukan untuk menghambat aktivitas dan pertumbuhan mikroorganisme yang dapat merusak bahan. Selain itu, bahan dengan kandungan air tinggi lebih sulit untuk diekstraksi minyaknya dengan pelarut non polar seperti heksan karena ketidaklarutannya dalam air. Cangkang dan biji hasil dari pengupasan buah nyamplung kemudian dikarakterisasi dengan menganalisis kadar air (AOAC 1995, 950.46), kadar minyak (SNI 01-2891-1992), kadar abu (AOAC 1995, 923.03), kadar protein (AOAC 1995, 991.20), kadar serat kasar (SNI-01-2891-1992) dan kadar karbohidrat (by difference).

Ekstraksi minyak dan resin diawali dengan pengecilan ukuran biji nyamplung. $100 \mathrm{~g}$ biji nyamplung dan $100 \mathrm{~mL}$ etanol digiling menggunakan blender selama 5 menit, kemudian ke dalamnya ditambahkan 200-400 mL heksan dan 100-300 mL etanol. Proses ekstraksi minyak dan resin dilakukan dalam labu leher tiga pada suhu $40^{\circ} \mathrm{C}$ dan $50^{\circ} \mathrm{C}$ dengan kecepatan pengadukan sekitar 800 rpm dan waktu ekstraksi 5 jam dan 7 jam. Setelah proses ekstraksi selesai, campuran minyak, resin dan pelarut dipisahkan dari ampas menggunakan penyaring vakum. Campuran minyak, resin dan pelarut kemudian dimasukkan ke dalam labu pemisah untuk memisahkan fraksi heksanminyak serta fraksi etanol-resin. Kedua fraksi tersebut selanjutnya dievaporasi untuk memisahkan minyak dari heksan dan resin dari etanol. Minyak dan resin yang diperoleh dipanaskan dalam oven pada suhu $105^{\circ} \mathrm{C}$ selama 1 jam untuk menguapkan heksan dan etanol yang masih tersisa, kemudian ditimbang bobotnya dan dihitung rendemennya menggunakan persamaan: rendemen $(\%)=[$ bobot minyak atau resin $(\mathrm{g}) /$ bobot biji $(\mathrm{g})] \times 100$.

Minyak nyamplung yang diperoleh dalam penelitian ini dikarakterisasi sifat fisikokimianya dengan menganalisis viskositas mengunakan rheometer, densitas (AOAC 2005, 920.212), bilangan asam (SNI 04-7182-2006) dan bilangan iod (SNI 3748-2006). Sifat fisikokimia resin dianalisis hanya dengan pengujian bilangan asam (SNI 047182-2006) saja.

Penelitian ini dirancang menggunakan acak lengkap yang disusun secara faktorial dengan faktor waktu ekstraksi (5 jam dan 7 jam), suhu $\left(40^{\circ} \mathrm{C}\right.$ dan $\left.50^{\circ} \mathrm{C}\right)$ dan nisbah heksan/etanol (2:4, 3:3 dan 4:2). Model matematik untuk rancangan acak lengkap dengan 3 faktor adalah sebagai berikut (Montgomery, 2001):

$$
\begin{aligned}
Y_{i j k}= & \mu+A_{i}+B_{j}+C_{k}+(A B)_{i j}+(A C)_{i k}+(B C)_{j k}+ \\
& (A B C)_{i j k}+\varepsilon_{i j k}
\end{aligned}
$$

Keterangan:

$\mathrm{Y}_{\mathrm{ijk}} \quad$ : Nilai respon untuk faktor A taraf ke-i, faktor B taraf ke-j dan faktor

\begin{tabular}{|c|c|c|}
\hline$\mu$ &. & Nilai rata-rata umum \\
\hline $\mathrm{A}_{\mathrm{i}}$ & : & $\begin{array}{l}\text { Pengaruh faktor waktu ekstraksi } \\
\text { pada taraf ke-i }\end{array}$ \\
\hline $\mathrm{B}_{\mathrm{j}}$ & : & $\begin{array}{l}\text { Pengaruh faktor suhu pada taraf } \\
\text { ke-j }\end{array}$ \\
\hline $\mathrm{C}_{\mathrm{k}}$ & : & $\begin{array}{l}\text { Pengaruh faktor nisbah antara } \\
\text { heksan dan etanol pada taraf ke-k }\end{array}$ \\
\hline$(\mathrm{AB})_{\mathrm{ij}}$ & : & $\begin{array}{l}\text { Pengaruh interaksi antara faktor A } \\
\text { taraf ke-i dan faktor B taraf ke-j }\end{array}$ \\
\hline$(\mathrm{AC})_{\mathrm{ik}}$ & : & $\begin{array}{l}\text { Pengaruh interaksi antara faktor A } \\
\text { taraf ke-i dan faktor C taraf ke-k }\end{array}$ \\
\hline$(\mathrm{BC})_{\mathrm{jk}}$ & : & $\begin{array}{l}\text { Pengaruh interaksi antara faktor B } \\
\text { taraf ke-j dan faktor C taraf ke-k }\end{array}$ \\
\hline$(\mathrm{ABC})_{\mathrm{ijk}}:$ & : & $\begin{array}{l}\text { Pengaruh interaksi antara faktor A } \\
\text { taraf ke-i, faktor B taraf ke-j, } \\
\text { faktor C taraf ke-k }\end{array}$ \\
\hline$\varepsilon_{\mathrm{ijk}}$ & & $\begin{array}{l}\text { Pengaruh galat dari faktor A taraf } \\
\text { ke-i, faktor B taraf ke-j dan faktor } \\
\text { C taraf ke-k. }\end{array}$ \\
\hline
\end{tabular}

\section{C taraf ke-k}

Setiap perlakuan dalam penelitian ini dilakukan dengan 2 kali ulangan. Untuk mengetahui pengaruh faktor-faktor tersebut, data yang diperoleh dianalisis keragamannya menggunakan $\alpha=0,05$ dan dilanjutkan dengan uji lanjut Duncan.

\section{HASIL DAN PEMBAHASAN}

Buah nyamplung yang digunakan pada penelitian ini terdiri dari $40 \%$ biji dan $60 \%$ cangkang (Gambar 1). Dari Tabel 1 dapat dilihat bahwa bagian biji dari buah nyamplung mengandung minyak yang sangat tinggi ( $\pm 75 \%$ bk atau $61 \%$ bb), sedangkan bagian cangkangnya banyak mengandung serat $( \pm$ $61 \% \mathrm{bb}$ ), yang terdiri dari hemiselulosa, selulosa dan lignin (Senthil dan Mohan 2015). Dengan demikian bagian biji dari buah nyamplung sangat potensial untuk dimanfaatkan sebagai sumber minyak nabati, sedangkan bagian cangkangnya sangat potensial untuk dimanfaatkan sebagai bahan baku dalam pembuatan pupuk organik, papan partikel, briket (Almu et al., 2014), arang aktif (Wibowo et al., 2010), dan sebagainya.

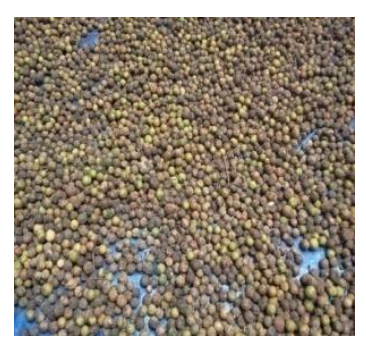

(a)

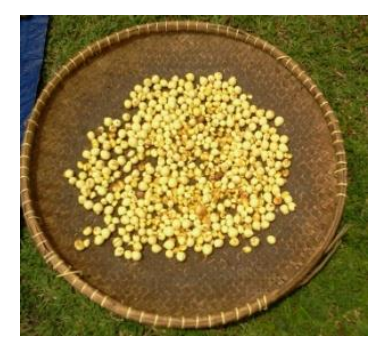

(b)
Gambar 1. (a) Bagian buah dan (b) inti biji nyamplung 
Tabel 1. Karakteristik biji dan cangkang hasil pengupasan buah nyamplung

\begin{tabular}{lcc}
\hline \multicolumn{1}{c}{ Parameter } & Biji & Cangkang \\
\hline Kadar air $(\%, b b)$ & $23,06 \pm 0,129$ & $14,76 \pm 0,456$ \\
Kadar abu $(\%, b b)$ & $1,47 \pm 0,004$ & $2,39 \pm 0,085$ \\
Kadar protein $(\%$, bb) & $6,61 \pm 0,636$ & $1,36 \pm 0,636$ \\
Kadar minyak $(\%$, bk) & $75,09 \pm 2,093$ & $4,89 \pm 0,109$ \\
Kadar serat $(\%, b b)$ & $2,17 \pm 0,089$ & $60,72 \pm 2,240$ \\
Kadar karbohidrat $($ by difference $)(\%, b b)$ & $5,68 \pm 2,309$ & $16,52 \pm 2,618$ \\
\hline
\end{tabular}

Biji nyamplung yang digunakan dalam penelitian ini mempunyai kadar minyak $(75,1 \%$ bk) dan kadar protein $(8,59 \%$ bk) yang lebih tinggi dibandingkan dengan kadar minyak $(63,1 \%$ bk) dan kadar protein $(3,42 \%$ bk) dari biji nyamplung yang digunakan oleh Chandra et al. (2013). Selain itu, kadar abu $(1,90 \%$ bk) dan seratnya $(2,82 \%$ bk) lebih kecil dari kadar abu $(3,22 \%$ bk) dan kadar serat (16,64\% bk) biji nyamplung yang digunakan oleh Chandra et al. (2013). Perbedaan-perbedaan tersebut dapat disebabkan karena adanya perbedaan varietas, umur panen, kondisi lingkungan pertumbuhan tanaman nyamplung dan penanganan pasca panennya. Buah nyamplung yang digunakan dalam penelitian ini berasal dari kawasan hutan dengan tujuan khusus (KHDTK) Carita (Banten) dan dipanen pada periode bulan Desember 2015-Januari 2016.

Biji nyamplung yang digunakan sebagai bahan baku pada proses ekstraksi minyak dan resin dalam penelitian ini adalah biji yang telah dikeringkan dalam oven pada suhu $50-70^{\circ} \mathrm{C}$ selama 48-72 jam, dan diketahui mempunyai kadar air 1-2\% (bb). Pengeringan dilakukan untuk menghambat aktivitas enzim yang dapat merusak bahan, serta aktivitas dan pertumbuhan mikroorganisme (Fadhlullah et al., 2015). Selain itu, kandungan air dalam bahan dapat mempengaruhi rendemen minyak yang dihasilkan (Jahirul et al., 2013; Fadhlullah et al., 2015). Bahan dengan kandungan air tinggi lebih sulit untuk diekstraksi minyaknya dengan heksan (Melanie dan Fithriani, 2015). Hal ini disebabkan karena heksan merupakan pelarut non polar yang tidak larut dalam air, sehingga kandungan air di permukaan dan dalam sel bahan menghalangi kontak antara pelarut dengan bagian sel yang mengandung minyak. Selain itu, kandungan air yang tinggi dalam bahan dapat menyebabkan terjadinya proses hidrolisis yang menurunkan mutu minyak.

Proses ekstraksi biji nyamplung yang dilakukan dalam penelitian ini menghasilkan rendemen minyak dan resin masing-masing berkisar antara $36-60 \%$ dan 3-17\%. Minyak mempunyai densitas $\left(25^{\circ} \mathrm{C}\right)$ sekitar $0,86-0,93 \mathrm{~g} / \mathrm{cm}^{3}$, viskositas $\left(25^{\circ} \mathrm{C}\right)$ sekitar 63-78 mPa.s, bilangan asam sekitar 6$20 \mathrm{mg} \mathrm{KOH} / \mathrm{g}$, dan bilangan iod sekitar 60-69 g iod/100 g. Resin yang dihasilkan pada penelitian ini mempunyai keasaman yang sangat tinggi dengan bilangan asam berkisar antara 108-152 mg KOH/g.

Hasil analisis keragaman terhadap rendemen minyak menunjukkan bahwa waktu ekstraksi (A), suhu (B), nisbah heksan/etanol (C), dan interaksi faktor-faktornya (AC dan $\mathrm{ABC}$ ) berpengaruh secara nyata terhadap rendemen minyak. Rendemen minyak meningkat secara signifikan dengan penurunan waktu ekstraksi dan suhu, serta peningkatan nisbah heksan/etanol (Gambar 2). Rendemen minyak tertinggi $(59,4 \%)$ dengan demikian diperoleh pada waku ekstraksi 5 jam, suhu $40^{\circ} \mathrm{C}$ dan nisbah heksan/etanol 4:2.

Peningkatan nisbah heksan/etanol meningkatkan secara signifikan rendemen minyak, ini membuktikan bahwa minyak nyamplung tergolong jenis minyak non polar karena asam lemak penyusunnya didominasi oleh asam-asam lemak rantai panjang seperti asam oleat $\left(\mathrm{C}_{18: 1}\right)$ dan asam linoleat $\left(\mathrm{C}_{18: 2}\right)$ (Crane et al., 2005; Hathurusingha et al., 2011a,b; Adewuyi et al., 2014). Menurut Margaretta et al. (2011) semakin lama waktu ekstraksi, maka rendemen akan semakin tinggi. Namun demikian, pada penelitian ini rendemen minyak dengan waktu ekstraksi 5 jam lebih tinggi dibandingkan dengan waktu ekstraksi 7 jam. Hal ini menandakan bahwa kondisi kesetimbangan telah tercapai dan minyak dapat diekstraksi secara optimal pada waktu ekstraksi 5 jam. Kondisi kesetimbangan dalam ekstraksi adalah keadaan dimana zat terlarut yang ada dalam bahan tidak dapat larut lagi dalam pelarut dan konsentrasi minyak dalam larutan tetap sama sebelum mengalami penurunan (Tagora et al., 2012). Ketika konsentrasi minyak dalam pelarut (heksan) sudah maksimal, maka pelarut tidak mampu lagi untuk mengikat minyak baik yang berada di dinding maupun di dalam sel (Sayyar et al., 2009).

Peningkatan suhu ekstraksi sebesar $10^{\circ} \mathrm{C}$ pada penelitian ini tidak meningkatkan rendemen minyak secara signifikan. Menurut Evon et al. (2007), peningkatan suhu pada umumnya dapat menyebabkan pori-pori padatan mengembang sehingga laju difusi pelarut ke dalam pori-pori bahan padat atau dinding sel dan pelarutan zat terlarut oleh pelarut di dalam sel meningkat, akibatnya rendemen dapat ditingkatkan dengan peningkatan suhu ekstraksi. Selain itu, suhu yang lebih tinggi juga dapat mempercepat laju difusi sehingga proses ekstraksi dapat berjalan lebih cepat (Abu-arabi et al., 2000; Margaretta et al., 2011). Namun demikian, pada penelitian ini penggunaan suhu sebesar $40^{\circ} \mathrm{C}$ sudah cukup optimal untuk mengekstraksi minyak dari biji nyamplung. 


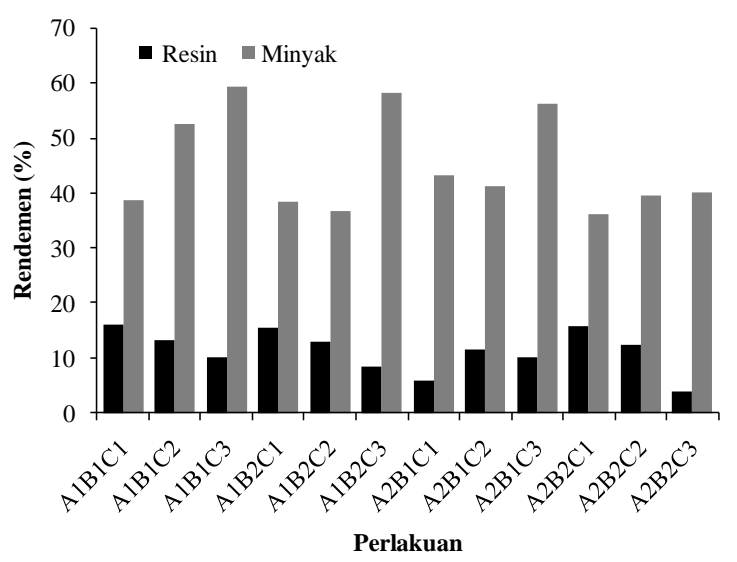

Keterangan:

$\mathrm{A}_{1}=$ waktu ekstraksi 5 jam, $\mathrm{A}_{2}=$ waktu ekstraksi 7 jam, $\mathrm{B}_{1}=$ suhu $40^{\circ} \mathrm{C}, \mathrm{B}_{2}=$ suhu $50^{\circ} \mathrm{C}, \mathrm{C}_{1}=$ nisbah heksan/etanol 2:4, $\mathrm{C}_{2}=$ nisbah heksan/etanol 3:3, $\mathrm{C}_{3}=$ nisbah heksan/etanol 4:2

Gambar 2. Rendemen minyak dan resin nyamplung pada berbagai perlakuan

Dibandingkan dengan hasil penelitian sebelumnya, rendemen minyak yang diperoleh dalam penelitian ini $(59,3 \%)$ lebih tinggi daripada yang diperoleh Jahirul et al. (2013) (51\%) dan Bhuiya et al. (2015) (54\%). Selain itu, besaran rendemen tersebut diperoleh pada waktu ekstraksi yang jauh lebih singkat (5 jam vs 48 jam) dan nisbah heksan terhadap biji nyamplung yang tidak berbeda banyak (4:1 vs 3:1).

Hasil analisis keragaman terhadap rendemen resin menunjukkan bahwa waktu ekstraksi (A), nisbah heksan/etanol (C) dan interaksi faktorfaktornya $(\mathrm{AB}, \mathrm{AC}, \mathrm{BC}$ dan $\mathrm{ABC})$ berpengaruh secara nyata terhadap rendemen resin. Rendemen resin meningkat secara signifikan dengan penurunan waktu ekstraksi dan nisbah heksan/etanol (Gambar 2). Rendemen resin tertinggi (16,2\%) dengan demikian diperoleh pada waku ekstraksi 5 jam, suhu $40^{\circ} \mathrm{C}$ dan nisbah heksan/etanol 2:4.

Gambar 2 memperlihatkan bahwa semakin rendah nisbah heksan/etanol atau semakin banyak jumlah etanol yang digunakan, rendemen resin cenderung semakin tinggi. Hal ini membuktikan bahwa resin lebih larut dalam pelarut polar (etanol) daripada pelarut non polar (heksan). Selain itu, semakin banyak pelarut (etanol) yang digunakan, luas kontak permukaan semakin meningkat dan perpindahan massa antara padatan dengan pelarut juga meningkat sehingga zat terlarut yang dapat terekstraksi semakin tinggi (Tagora et al., 2012; Yulviyanti et al., 2014). Seperti halnya minyak, kondisi kesetimbangan untuk mengekstraksi resin dicapai pada waktu ekstraksi selama 5 jam. Pada waktu ekstraksi > 5 jam, laju difusi mengalami penurunan akibat konsentrasi resin dalam etanol sudah maksimal sehingga etanol tidak mampu lagi mengikat resin yang tersisa di dalam sel (Sayyar et al., 2009). Demikian pula dengan suhu ekstraksi, cukup diset pada $40^{\circ} \mathrm{C}$ untuk mendapatkan rendemen resin yang optimal. Suhu yang lebih tinggi umumnya dapat meningkatkan efisiensi ekstraksi resin akibat adanya peningkatan energi kinetik, sehingga solubilitas resin yang berada dalam sel meningkat dan pelarut lebih mudah untuk memisahkan resin yang terikat oleh daya tarik antar molekul (Ashgari et al., 2011). Dibandingkan dengan rendemen resin tertinggi (14,9\%) yang diperoleh dari proses ekstraksi biji pala dengan etanol (Assagaf et al., 2012), rendemen resin $(16,1 \%)$ yang diperoleh dari penelitian ini nilainya lebih tinggi. Selain itu, besaran rendemen tersebut diperoleh pada suhu ekstraksi yang lebih rendah $\left(40^{\circ} \mathrm{C}\right.$ vs $\left.52^{\circ} \mathrm{C}\right)$, nisbah etanol terhadap bahan yang lebih rendah (4:1 vs 5:1) dan waktu ekstraksi yang sama $( \pm 5$ jam $)$.

Berdasarkan hasil kedua parameter rendemen tersebut, nisbah heksan terhadap etanol merupakan faktor yang lebih signifikan mempengaruhi rendemen minyak dan resin dibandingkan waktu dan suhu ekstraksi. Semakin tinggi nisbah pelarut heksan terhadap etanol, rendemen minyak semakin meningkat sedangkan rendemen resin semakin menurun. Demikian sebaliknya semakin rendah nisbah pelarut heksan terhadap etanol, rendemen minyak menurun sedangkan rendemen resin meningkat. Pada proses ekstraksi biji nyamplung dengan pelarut, heksan berfungsi untuk mengesktraksi minyak, sedangkan etanol berfungsi untuk mengesktraksi resin. Minyak dapat larut dengan baik dalam heksan karena keduanya bersifat non polar, sedangkan resin karena bersifat polar larut dalam etanol yang juga bersifat polar. Fenomena tersebut juga teramati oleh Taifan et al. (2013) bahwa resin pada biji nyamplung larut di dalam pelarut agak polar seperti etanol, sedangkan minyak larut dalam pelarut non polar seperti heksan.

Kandungan resin dalam biji nyamplung menyebabkan minyak nyamplung yang dihasilkan dari proses ekstraksi dengan cara mekanik bersifat toksik karena resin mengandung senyawa-senyawa beracun seperti ester asam fitalat, inofilum A-E, kalofiloid, asam kalofinat, dan polimer proantisoanidin. Menurut Dalvi et al. (2012), kandungan resin dalam minyak nyamplung dari proses ekstraksi dengan cara mekanik berkisar antara 10-30\%. Metode ekstraksi dengan menggunakan campuran pelarut heksan dan etanol seperti yang dilakukan pada penelitian ini dapat dengan mudah memisahkan minyak dari resin dimana hal tersebut sulit dilakukan pada metode sebelumnya. Dengan demikian, minyak yang dihasilkan pada penelitian ini dapat terbebas dari resin dan dapat dikonsumsi setelah melalui proses pemurnian, selain pemanfaatannya untuk keperluan non pangan. Di lain pihak, resinnya dapat digunakan untuk keperluan non pangan, seperti untuk vernis (Dalvi et al., 2012) dan produk-produk farmasi dan kosmetika (Athari dan Nasir, 2004; Dai dan Mumper, 2010; Ashgari et al., 2011). 
Tabel 2. Sifat fisikokimia minyak dan resin yang dihasilkan dari proses ekstraksi biji nyamplung pada berbagai perlakuan

\begin{tabular}{|c|c|c|c|c|c|c|c|}
\hline \multirow[b]{2}{*}{ Waktu (Jam) } & \multirow[b]{2}{*}{ Suhu $\left({ }^{\circ} \mathbf{C}\right)$} & \multirow{2}{*}{$\begin{array}{c}\text { Nisbah } \\
\text { Heksan/Metanol }\end{array}$} & \multicolumn{4}{|c|}{ Minyak } & \multirow{2}{*}{$\begin{array}{c}\text { Resin } \\
\begin{array}{c}\text { Bilangan Asam } \\
(\mathrm{mg} \mathrm{KOH} / \mathrm{g})\end{array} \\
\end{array}$} \\
\hline & & & $\begin{array}{c}\text { Bilangan Asam } \\
(\mathrm{mg} \mathrm{KOH} / \mathrm{g})\end{array}$ & $\begin{array}{c}\text { Bilangan Iod (g } \\
\text { iod } / 100 \mathrm{~g})\end{array}$ & $\begin{array}{c}\text { Viskositas }\left(25^{\circ} \mathrm{C}\right. \\
\text { mPa.s })\end{array}$ & $\begin{array}{c}\text { Densitas }\left(25^{\circ} \mathrm{C},\right. \\
\left.\mathrm{g} / \mathrm{cm}^{3}\right)\end{array}$ & \\
\hline 5 & 40 & $2: 4$ & $13,14 \pm 0,70$ & $62,84 \pm 0,05$ & $77,60 \pm 1,36$ & $0,91 \pm 0,00$ & $135,21 \pm 5,15$ \\
\hline 5 & 40 & $3: 3$ & $11,31 \pm 0,13$ & $63,66 \pm 0,58$ & $66,50 \pm 13,92$ & $0,88 \pm 0,01$ & $109,86 \pm 3,61$ \\
\hline 5 & 40 & $4: 2$ & $17,80 \pm 0,04$ & $63,79 \pm 2,09$ & $69,43 \pm 1,73$ & $0,89 \pm 0,00$ & $133,75 \pm 3,08$ \\
\hline 5 & 50 & $2: 4$ & $6,85 \pm 0,11$ & $68,63 \pm 1,33$ & $71,46 \pm 1,10$ & $0,91 \pm 0,01$ & $151,72 \pm 5,35$ \\
\hline 5 & 50 & $3: 3$ & $11,27 \pm 0,08$ & $64,53 \pm 1,11$ & $69,52 \pm 6,92$ & $0,91 \pm 0,00$ & $118,97 \pm 4,97$ \\
\hline 5 & 50 & $4: 2$ & $14,89 \pm 0,16$ & $60,75 \pm 1,51$ & $69,08 \pm 9,45$ & $0,86 \pm 0,00$ & $111,81 \pm 2,10$ \\
\hline 7 & 40 & $2: 4$ & $6,95 \pm 0,05$ & $63,91 \pm 0,88$ & $71,40 \pm 0,54$ & $0,91 \pm 0,00$ & $152,02 \pm 1,27$ \\
\hline 7 & 40 & $3: 3$ & $11,51 \pm 0,04$ & $66,30 \pm 1,24$ & $63,70 \pm 2,52$ & $0,91 \pm 0,01$ & $121,92 \pm 7,85$ \\
\hline 7 & 40 & $4: 2$ & $17,19 \pm 0,11$ & $65,25 \pm 1,88$ & $68,54 \pm 1,91$ & $0,89 \pm 0,00$ & $108,43 \pm 1,54$ \\
\hline 7 & 50 & $2: 4$ & $6,41 \pm 0,18$ & $66,39 \pm 0,77$ & $68,27 \pm 5,60$ & $0,91 \pm 0,01$ & $141,37 \pm 1,32$ \\
\hline 7 & 50 & $3: 3$ & $9,91 \pm 1,12$ & $64,91 \pm 1,93$ & $68,05 \pm 6,49$ & $0,91 \pm 0,01$ & $141,32 \pm 5,20$ \\
\hline 7 & 50 & $4: 2$ & $19,15 \pm 0,84$ & $65,71 \pm 1,49$ & $68,24 \pm 1,28$ & $0,92 \pm 0,00$ & $114,64 \pm 4,01$ \\
\hline
\end{tabular}


Proses ekstraksi resin pada suhu rendah $\left(35-60^{\circ} \mathrm{C}\right)$ dengan menggunakan pelarut etanol tidak merusak senyawa-senyawa aktif yang terkandung di dalamnya sehingga resin yang diperoleh dapat digunakan untuk keperluan pharmasi dan kosmetika (Bingjun, 2009).

Mutu minyak dan resin nyamplung yang dihasilkan pada penelitian ini disajikan pada Tabel 2. Kondisi proses ekstraksi secara umum mempengaruhi mutu minyak dan resin nyamplung yang dihasilkan. Bilangan asam merupakan salah satu parameter penting dalam penentuan mutu minyak nabati. Semakin rendah bilangan asam, maka semakin tinggi mutu minyak yang dihasilkan. Minyak dengan bilangan asam rendah lebih stabil sehingga umur simpannya lebih lama (Nwabueze dan Okocha, 2008; Dasari dan Goud, 2013). Minyak yang stabil tidak mudah bereaksi dengan keadaan sekitarnya, seperti udara, cahaya dan panas sehingga tidak mudah rusak. Hasil analisis keragaman terhadap bilangan asam minyak nyamplung menunjukkan bahwa waktu ekstraksi (A), suhu (B), nisbah heksan/etanol (C) dan interaksi faktorfaktornya ( $\mathrm{AB}, \mathrm{AC}, \mathrm{BC}$ dan $\mathrm{ABC}$ ) berpengaruh secara nyata terhadap bilangan asam. Bilangan asam minyak nyamplung menurun secara signifikan dengan meningkatnya waktu ekstraksi dan suhu, serta menurunnya nisbah heksan/etanol. Bilangan asam terendah, yaitu 6,41-6,95 $\mathrm{mg} \mathrm{KOH} / \mathrm{g}$, diperoleh pada nisbah heksan/etanol 2:4, suhu 40$50^{\circ} \mathrm{C}$ dan waku ekstraksi 5-7 jam (Tabel 2). Minyak dengan bilangan asam lebih tinggi (17,19-19,15 mg $\mathrm{KOH} / \mathrm{g}$ ) diperoleh pada nisbah heksan/etanol 4:2, suhu $40-50^{\circ} \mathrm{C}$ dan waku ekstraksi 5-7 jam. Hal ini menunjukkan bahwa bilangan asam minyak lebih dipengaruhi oleh nisbah heksan/etanol dibandingkan waktu dan suhu ekstraksi. Semakin tinggi nisbah heksan/etanol, semakin tinggi pula bilangan asam minyak. Pada penelitian ini pelarut heksan tidak hanya mengekstraksi trigliserida, tetapi juga melarutkan asam-asam lemak bebas, khususnya asam-asam lemak dengan rantai karbon panjang seperti asam oleat dan linoleat. Asam lemak yang memiliki rantai karbon panjang akan mudah larut dalam pelarut non polar seperti heksan, sedangkan asam lemak dengan rantai karbon pendek akan mudah larut dalam pelarut polar (Swern, 1982).

Dibandingkan dengan minyak nyamplung yang diperoleh dari proses ekstraksi dengan screw press (Kartika et al., 2010), minyak nyamplung yang diperoleh dari penelitian ini memiliki bilangan asam yang jauh lebih rendah (6-20 mg KOH/g vs 35-54 $\mathrm{mg} \mathrm{KOH} / \mathrm{g}$ ) dan berwarna kuning jernih. Selain itu, bilangan asam minyak nyamplung yang diperoleh dari penelitian ini juga lebih rendah daripada yang diperoleh oleh Jahirul et al. (2015) pada kasus ekstraksi minyak nyamplung dengan heksan (24 mg $\mathrm{KOH} / \mathrm{g}$ ) dan Hasibuan et al. (2013) pada kasus minyak nyamplung hasil proses degumming (29,2 $\mathrm{mg} \mathrm{KOH} / \mathrm{g}$ ). Hal ini menunjukkan bahwa minyak nyamplung yang diperoleh dari penelitian ini lebih bersih dan relatif sudah terbebas dari resin.

Bilangan asam merupakan parameter mutu yang penting untuk aplikasi minyak nyamplung sebagai bahan bakar nabati (BBN). Mesin diesel membutuhkan bahan bakar dengan bilangan asam ataupun kadar asam lemak bebas serendah mungkin, karena kandungan asam yang tinggi dalam bahan bakar dapat menimbulkan korosi dan deposit pada mesin (Knothe, 2006).

Hasil analisis keragaman untuk bilangan asam resin menunjukkan hanya nisbah heksan/etanol (C) dan interaksi faktor-faktornya (AC, BC dan ABC) yang berpengaruh secara nyata terhadap bilangan asam resin. Bilangan asam resin meningkat secara signifikan dengan menurunnya nisbah heksan/etanol. Bilangan asam resin tertinggi, yaitu 151,72-152,02 mg KOH/g, diperoleh pada nisbah heksan/etanol 2:4, suhu $40-50^{\circ} \mathrm{C}$ dan waku ekstraksi 5-7 jam (Tabel 2). Resin dengan bilangan asam lebih rendah (< $115 \mathrm{mg} \mathrm{KOH/g}$ ) diperoleh pada nisbah heksan/etanol 4:2, suhu $40-50^{\circ} \mathrm{C}$ dan waku ekstraksi 5-7 jam. Hal ini menunjukkan bahwa bilangan asam resin lebih dipengaruhi oleh nisbah heksan/etanol dibandingkan waktu dan suhu ekstraksi, seperti halnya bilangan asam minyak.

Tabel 2 juga menunjukkan bahwa bilangan asam resin (>102 mg KOH/g) nilainya jauh lebih tinggi dibandingkan dengan bilangan asam minyak $(<20 \mathrm{mg} \mathrm{KOH} / \mathrm{g})$. Hal ini menunjukkan kandungan asam lemak bebas di dalam resin $(>51 \%)$ jauh lebih tinggi dibandingkan dalam minyak $(<10 \%)$. Asam lemak bebas yang terkandung pada minyak nyamplung lebih didominasi oleh asam-asam lemak yang bersifat non polar seperti asam oleat dan linoleat, sedangkan yang terkandung dalam resin kemungkinan lebih didominasi oleh asam-asam lemak yang bersifat polar seperti asam palmitat dan stearat. Selain asam lemak bebas, resin juga mengandung asam benzoat (Prabakaran dan Britto, 2012), asam kalofinat, senyawa-senyawa turunan asam sinamat, asam begonia, serta senyawa-senyawa fenolik dan polifenolik (Liu et al., 2015) yang menyebabkan keasamannya menjadi sangat tinggi. Asam dan senyawa-senyawa tersebut ikut terekstraksi oleh etanol karena sifatnya yang polar dan larut dalam etanol.

Bilangan iod merupakan parameter mutu lainnya untuk minyak nabati. Bilangan ini dapat dijadikan sebagai indikator untuk menentukan golongan minyak, yaitu minyak non- pengering, semi-pengering dan pengering (Ochigbo dan Ikechukwu, 2011). Hasil analisis keragaman menunjukkan bahwa waktu ekstraksi (A), nisbah heksan/etanol (C), dan interaksi faktor-faktornya (AC, BC dan ABC) berpengaruh secara nyata terhadap bilangan iod minyak nyamplung. Semakin lama waktu ekstraksi dan semakin kecil nisbah heksan/etanol, bilangan iod minyak nyamplung semakin meningkat. Bilangan iod minyak tertinggi 
(68,63 g iod/100 g minyak) diperoleh dari waktu ekstraksi 5 jam, suhu $50^{\circ} \mathrm{C}$ dan nisbah heksan/etanol $2: 4$, sedangkan bilangan iod terendah $(60,75 \mathrm{~g}$ iod/100 g minyak) diperoleh dari waktu ekstraksi 5 jam, suhu $50^{\circ} \mathrm{C}$ dan nisbah heksan/etanol 4:2 (Tabel 2).

Berdasarkan nilai bilangan iod tersebut, minyak nyamplung yang dihasilkan pada penelitian ini tergolong ke dalam minyak non-pengering $(<100$ $\mathrm{g}$ iod/100 g minyak). Menurut Adewuyi et al. (2014), komposisi asam lemak minyak nyamplung didominasi oleh asam lemak tidak jenuh $(61,4 \%)$, seperti asam palmitoleat, asam oleat, asam linoleat dan asam linolenat. Asam oleat $(36,88 \%)$ dan asam linoleat $(23,90 \%)$ merupakan asam lemak utama yang terkandung dalam minyak nyamplung. Oleh karena itu minyak nyamplung yang diperoleh dari penelitian ini baik digunakan sebagai bahan baku untuk biodiesel, produk-produk kosmetika dan pharmasi. Minyak nyamplung dengan bilangan iod yang rendah sangat potensial digunakan sebagai sumber minyak nabati untuk bahan baku shampo, kondisioner, losion, krim, salep dan produk kosmetik lainnya dalam bentuk cair, pasta atau bubuk (Axelrod dan Gajria, 2011). Minyak nyamplung sering digunakan secara khusus untuk penyakit kulit dan rematik (Athari dan Nasir, 2014; Prabakaran dan Britto, 2012; Kilham, 2004). Hal ini disebabkan minyak nyamplung memiliki efek pelembab untuk kulit, menyembuhkan efek iritasi seperti inflamasi dan ruam merah pada kulit, eskim, serta menyembuhkan luka dan mencegah infeksi.

Selain bilangan asam, minyak nabati dengan bilangan iod rendah lebih disukai apabila aplikasinya sebagai bahan bakar nabati (Kartika et al., 2010). Minyak nabati dengan bilangan iod tinggi akan menyebabkan pembentukan deposit/kerak pada lubang saluran injeksi, piston, dan lainnya. Hal ini dapat terjadi karena adanya ketidakstabilan ikatan rangkap oleh suhu panas. Untuk itu minyak yang akan digunakan sebagai bahan bakar nabati harus memiliki bilangan iod yang lebih rendah dari 115 $\mathrm{mg}$ Iod/g, dan minyak nyamplung potensial digunakan sebagai bahan bakar nabati, khususnya sebagai Pure Plant Oil (PPO) atau biofuel.

Parameter fisik yang menentukan mutu minyak nabati adalah densitas dan viskositas. Semakin tinggi densitas dan viskositas minyak nabati, maka mutunya semakin rendah karena hal tersebut menunjukkan zat-zat pengotor yang terkandung dalam minyak tersebut semakin banyak. Hasil analisis keragaman untuk densitas menunjukkan bahwa waktu ekstraksi (A), suhu (B), nisbah heksan/etanol (C) dan interaksi faktorfaktornya $(\mathrm{AB}, \mathrm{AC}, \mathrm{BC}$ dan $\mathrm{ABC})$ berpengaruh secara signifikan terhadap densitas. Peningkatan waktu ekstraksi dan suhu menyebabkan densitas minyak juga meningkat. Sebaliknya, peningkatan nisbah heksan/etanol menyebabkan densitas minyak menurun. Hal tersebut menunjukkan bahwa kandungan zat-zat pengotor dalam minyak semakin meningkat dengan peningkatan waktu ekstraksi, suhu dan nisbah etanol/heksan. Zat-zat pengotor tersebut dapat berupa resin, asam lemak bebas, alkaloid, fosfatida, karotenoid, klorofil, dan lain-lain (Muhammad et al., 2014). Selain itu, zat-zat pengotor lebih banyak yang terekstraksi ketika waktu ekstraksi lebih lama, suhu lebih tinggi dan jumlah etanol yang digunakan lebih banyak daripada heksan. Peningkatan densitas minyak dengan waktu ekstraksi juga teramati oleh Nasir et al. (2009) pada kasus ekstraksi minyak dedak, sedangkan peningkatannya dengan suhu ekstraksi teramati oleh Handayani et al. (2010) pada kasus ekstraksi minyak wijen.

Densitas minyak nyamplung yang diperoleh dalam penelitian ini berkisar antara $0.86-0,93 \mathrm{~g} / \mathrm{cm}^{3}$ (Tabel 2). Hasil ini tidak berbeda jauh dengan densitas minyak nyamplung yang diperoleh dari proses ekstraksi secara mekanik yang berkisar antara 0,91-0,93 g/cm 3 (Fadhlullah et al., 2015), densitas minyak nabati pada umumnya, yaitu $\pm 0,9 \mathrm{~g} / \mathrm{cm}^{3}$, dan densitas minyak diesel (solar) $\left(0,82-0,87 \mathrm{~g} / \mathrm{cm}^{3}\right)$. Oleh karena itu minyak nyamplung potensial digunakan sebagai bahan bakar nabati, khususnya sebagai Pure Plant Oil (PPO) atau biofuel.

Hasil analisis keragaman untuk viskositas minyak menunjukkan bahwa waktu ekstraksi, suhu dan nisbah heksan/etanol dan interaksi faktorfaktornya tidak berpengaruh secara nyata terhadap viskositas. Nilai viskositas minyak nyamplung relatif konstan pada berbagai perlakuan yang diuji pada penelitian ini (Tabel 2).

Dibandingkan dengan minyak nyamplung yang diperoleh dari proses ekstraksi secara mekanik (Boucher, 2000), minyak nyamplung yang diperoleh dari penelitian ini memiliki viskositas pada suhu $25^{\circ} \mathrm{C}$ yang lebih rendah (63-78 mPa.s vs > 98 mPa.s). Hal ini menunjukkan bahwa minyak nyamplung yang diperoleh dari penelitian ini kandungan zat-zat pengotornya, khususnya resin, lebih rendah.

Uji skoring terhadap seluruh parameter yang diuji dalam panelitian ini menghasilkan perlakuan terbaik untuk proses ekstraksi minyak dari biji nyamplung adalah waktu ekstraksi 5 jam, suhu $50^{\circ} \mathrm{C}$ dan nisbah heksan/etanol 4:2 dengan rendemen minyak yang diperoleh sebesar 58,2\%. Minyak nyamplung hasil dari perlakuan ini mempunyai bilangan asam 14,89 $\mathrm{mg} \mathrm{KOH} / \mathrm{g}$, bilangan iod 60,75 $\mathrm{g}$ iod $/ 100 \mathrm{~g}$, viskositas $\left(25^{\circ} \mathrm{C}\right) 71,46 \mathrm{mPa} . \mathrm{s}$ dan densitas $\left(25^{\circ} \mathrm{C}\right) 0,86 \mathrm{~g} / \mathrm{cm}^{3}$. Dari perlakuan tersebut juga diperoleh resin dengan rendemen sebesar 8,6\% dan bilangan asamnya sebesar 111,82 mg KOH/g. Perlakuan terbaik untuk proses ekstraksi resin dari biji nyamplung adalah waktu ekstraksi 5 jam, suhu $40^{\circ} \mathrm{C}$ dan nisbah heksan/etanol 2:4 dengan rendemen resin yang diperoleh sebesar 16,2\% dan bilangan asam 133,76 mg KOH/g. Dari perlakuan ini juga diperoleh minyak dengan rendemen sebesar $38,7 \%$ 
dan mutunya sebagai berikut: bilangan asam 13.14 $\mathrm{mg} \mathrm{KOH} / \mathrm{g}$, bilangan iod $62,72 \mathrm{~g}$ iod/100 g, viskositas $\left(25^{\circ} \mathrm{C}\right) 69,43 \mathrm{mPa} . \mathrm{s}$ dan densitas $\left(25^{\circ} \mathrm{C}\right)$ $0,91 \mathrm{~g} / \mathrm{cm}^{3}$.

\section{KESIMPULAN DAN SARAN}

\section{Kesimpulan}

Kondisi proses ekstraksi biji nyamplung dengan menggunakan campuran pelarut heksanetanol secara umum berpengaruh terhadap rendemen dan mutu minyak dan resin yang dihasilkan, dan faktor nisbah heksan/etanol pengaruhnya lebih dominan daripada waktu dan suhu ekstraksi. Rendemen minyak terbaik $(58,2 \%)$ diperoleh pada waktu ekstraksi 5 jam, suhu $50^{\circ} \mathrm{C}$ dan nisbah heksan/etanol 4:2, dan rendemen resin terbaik $(16,2 \%)$ diperoleh pada waktu ekstraksi 5 jam, suhu $40^{\circ} \mathrm{C}$ dan nisbah heksan/etanol 2:4. Minyak nyamplung hasil perlakuan tersebut mempunyai bilangan asam 14,89 $\mathrm{mg} \mathrm{KOH} / \mathrm{g}$, bilangan iod 60,75 $\mathrm{g}$ iod $/ 100 \mathrm{~g}$, viskositas $\left(25^{\circ} \mathrm{C}\right) 71,46 \mathrm{mPa} . \mathrm{s}$ dan densitas $\left(25^{\circ} \mathrm{C}\right) 0,86 \mathrm{~g} / \mathrm{cm}^{3}$, dan resin nyamplung mempunyai bilangan asam 133,76 mg KOH/g.

\section{Saran}

Nisbah heksan/etanol perlu ditingkatkan untuk meningkatkan rendemen minyak dan resin. Selain itu, minyak dan resin perlu dianalisis kandungan senyawa-senyawa fenolik, polifenolik, kumarin, xanton dan ester asam fitalatnya.

\section{UCAPAN TERIMA KASIH}

Penulis mengucapkan terima kasih kepada Direktorat Riset dan Pengabdian Masyarakat, Direktorat Jenderal Penguatan Riset dan Pengembangan KEMENRISTEKDIKTI atas bantuan dana (Hibah Kompetitif Strategis Nasional) untuk pelaksanaan penelitian ini.

\section{DAFTAR PUSTAKA}

Abu-Arabi MK, Allawzi MA, Al-Zoubi HS, Tamimi A. 2000. Extraction of jojoba oil by pressing and leaching. Chemical Engineering Journal. 76:61-65.

Adewuyi A, Fasusi OH, dan Odorinde RA. 2014. Antibacterial activities of acetonides prepare from the seeds oil of Calophyllum inophyllum and Pterocarpus osun. Journal of Acute Medicine. 4:75-80.

Almu M, Syahrul, dan Padang YA. 2014. Analisa nilai kalor dan laju pembakaran pada briket campuran biji nyamplung (Calophyllum inophyllum) dan abu sekam. Dinamika Teknik Mesin. 4(2):117-122.

Anggraini D, Istianingsih D, dan Gunawan S. 2014. Pengaruh prosentase solvent non polar dalam campuran pelarut terhadap pemisahan senyawa non polar dari minyak nyamplung (Calophyllum inophyllum). Jurnal Teknik Pomits. 3(1):23-26.

Ashgari J, Ondruschka B, dan Mazaheritehrani M. 2011. Extraction of bioactive chemical compounds from the medicinal asian plants by microwave irradiation. Journal of Medicinal Plants Research. 5(4):495-506.

Assagaf M, Hastuti P, Hidayat C, Supriyadi. 2012. Optimasi ekstraksi oleoresin pala (Myristica fragrans Houtt) asal Maluku Utara menggunakan response surface methodology (RSM). Agritech. 32(1):383390.

Atabani AE dan César AS. 2014. Calophyllum inophyllum L.- A prospective non-edible biodiesel feedstock. Study of biodiesel production, properties, fatty acid composition, blending and engine performance. Renewable and Sustainable Energy Reviews. 37:644-655.

Athari M dan Nasir SM. 2004. Taxonomic perspective of plant species yielding vegetable oils used in cosmetics and skin care product. Africa Journal of Biotechnology. 4(1):36-44.

Axelrod GS dan Gajria A. 2011. Tamanu Oil Product. US Patent. US7959905B2.

Bhuiya MMK, Rasul MG, Khan MMK, Ashwath, Azad AK, Mofijur M. 2015. Optimisation of oil extraction process from Australian native beauty leaf seed (Calophyllum inophyllum). Energy Procedia. 75:56-61.

Bingjun H. 2009. Method for extracting Calophyllum essential oil constituent. China Patent. CN101497846A.

Boucher C. 2000. Calophyllum oil extracted at ambient temperature has UV protecting, antiradical, antioxidant, anti aging and therapeutic properties. FR9907772A.

Bustoni S, Rostiwati R, Sudrajat R, Kosasih S, Anggraini I, Leksono B, et al. 2009. Nyamplung (Calophyllum inophyllum L) Sumber Energi Biofuel Yang Potensial. Bogor (ID): Badan Litbang Kehutanan.

Chandra BB, Setiawan F, Gunawan S, Widjaja T. 2013. Pemanfaatan biji buah nyamplung (Calophyllum inophyllum) sebagai bahan baku pembuatan biodisel. Jurnal Teknik Pomits 2(1):13-15.

Chavan SB, Kumbhar RR, dan Deshmukh RB. 2013. Calophyllum inophyllum Linn ("honne") oil, a source for biodiesel production. Research Journal of Chemical Science. 3(11):24-31.

Crane S, Aurore G, Joseph H, Mouloungui Z, Bourgeois P. 2005. Composition of fatty acids triacylglycerols and unsaponifiable matter in Calophyllum calaba L. oil from Guadeloupe. Phytochemistry 66:1821-1831. 
Dai J dan Mumper RJ. 2010. Plant phenolic: Extraction, analysis and their antioxidant and anticancer properties. Molecules 15(10):7313-7352.

Dalvi S, Sonawane S, dan Pokharkar R. 2012. Preparation of biodiesel of undi seed with in-situ transesterification. Leonardo Electronic Journal of Practices and Technologies 20:175-182.

Dasari SR dan Goud VV. 2013. Comparative extraction of castor seed oil using polar and non polar solvents. International Journal of Current Engineering and Technology 3:121-123.

Dweck AC dan Meadows T. 2002. Tamanu (Calophyllum inophyllum) - The African, Asian, Polynesian and Pacific Panacea. International Journal of Cosmetic Science 24:1-8.

Evon P, Vandenbossche V, Pontalier PY, Rigal L. 2007. Direct extraction of oil from sunflower seeds by twin-screw extruder according to an aqueous extraction process: Feasibility study and influence of operating conditions. Industrial Crops and Products 26:351-359.

Fadhlullah M, Widiyanto SNB, Elvi Restiawaty E. 2015. The potential of nyamplung (Calophyllum inophyllum L.) seed oil as biodiesel feedstock: Effect of seed moisture content and particle size on oil yield. Energy Procedia 68:177-185.

Handajani S, Manuhara GJ, dan Anandito RBK. 2010. Pengaruh suhu ekstraksi terhadap karakteristik fisik, kimia dan sensoris minyak wijen (Sesamun indicum L.) Agritech 30(2):116-122.

Hasibuan S, Sahirman, dan Yudawati NMA. 2013. Karakteristik fisikokimia dan antibakteri hasil purifikasi minyak biji nyamplung (Calophyllum inophyllum L.). Agritech 33(3):311-319.

Hathurusingha S, Ashwath N, dan Subedi P. 2011a. Variation in oil content and fatty acid profile of Calophyllum inophyllum L. with fruit maturity and its implications on resultant biodiesel quality. Industrial Crops and Products 33:629-632.

Hathurusingha S, Ashwath N, dan Midmore D. 2011b. Periodic variation in kernel oil content and fatty acid profiles of Calophyllum inophyllum L.: A potential biodiesel feedstock in Australia. Biomass and Bioenergy 35:3448-3452.

Heyne K. 1987. Tumbuhan Berguna Indonesia. Terjemahan. Jakarta (ID): Badan Libang Kehutanan, Departemen Kehutanan Jakarta Pusat.

Jahirul MI, Brown RJ, Senadeera W, Ashwath N, Laing C, Leski-Taylor J, Rasul MG. 2013.
Optimisation of bio-oil extraction process from beauty leaf (Calophyllum inophyllum) oil seed as a second generation biodiesel source. Procedia Engineering 56:619-624.

Jahirul MI, Brown RJ, Senadeera W, Ashwath N, Rasul MG, Rahman MM. 2015. Physiochemical assessment of beauty leaf (Calophyllum inophyllum) as secondgeneration biodiesel feedstock. Energy Reports 1:204-215.

Jos B, Pramudono B, dan Aprianto. 2011. Ekstraksi resin dari kayu manis berbantu ultrasonik dengan menggunakan pelarut alkohol. Reaktor 13(4):231-236.

Kartika IA, Fathiyah S, Desrial, Purwanto YA. 2010. Pemurnian minyak nyamplung dan aplikasinya sebagai bahan bakar nabati. Jurnal Teknologi Industri Pertanian 20(2):122-129.

Kilham C. 2004. Tamanu oil: A tropical remedy. HerbalGram 63:26-31.

Knothe G. 2006. Analyzing biodiesel: Standards and other methods. Journal of the American Oil Chemists' Society 83:823-833.

Leksono B, Hendrati RL, Windyarini E, Hasnah T. 2014. Variation of biofuel potential of 12 Calophyllum inophyllum populations in Indonesia. Indonesian Journal of Forestry Research 1(2):127-138.

Liu W, Liu Y, Chen Z, Chiou W, Tsai Y, Chen C. 2015. Calophyllolide content in Calophyllum inophyllum at different stage of maturity and its osteogenic activity. Molecules 20(7):12314-12327.

Margaretta S, Handayani SD, Indraswati N, Hindarso H. 2011. Ekstraksi senyawa phenolik Pandanus amaryllifolius Roxb sebagai antioksidan alami. Widya Teknik 10(1):21-30.

Melanie S dan Fithriani D. 2015. Rendemen minyak dari mikroalga Spirulina sp. dan Chlorella $s p$. dengan teknik pemecahan dinding sel. Widyariset 1(1):61-70.

Montgomery DC. 2001. Design and Analysis of Experimental $5^{\text {th }}$ Edition. New York: John Wiley and Son.

Muhammad FR, Jatranti S, Qadriyah L, Mahfud. 2014. Pembuatan biodiesel dari minyak nyamplung menggunakan pemanasan gelombang mikro. Jurnal Teknik Pomits 3(2):154-159.

Nasir S, Fitriyanti, dan Karmila H. 2009. Ekstraksi dedak padi menjadi minyak mentah dedak padi (crude rice brain oil) dengan pelarut nheksan dan etanol. Jurnal Teknik Kimia 16(2):1-10.

Nwabueze TU dan Okocha KS. 2008. Extraction performances of polar and non-polar solvents on the physical and chemical indices of African Bread fruit (Treculia 
africana) seed oil. African Journal of Food Science (2): $119-125$

Ochigbo SS dan Ikechukwu AA. 2011. Effect of presence of free fatty acids on the drying of oil/drying catalysts mixtures. African Journal of Pure and Applied Chemistry 5(7):198-203.

Ong HC, Masjuki HH, Mahlia TMI, Silitonga AS, Chong WT, Leong KY. 2014. Optimization of biodiesel production and engine performance from high free fatty acid Calophyllum inophyllum oil in CI diesel engine. Energy Conversion and Management 81:30-40.

Prabakaran K dan Britto SJ. 2012. Biology, agroforestry and medicinal value of Calophyllum inophyllum L. (clusiacea): A review. International Journal of Natural Product Research 1(2):24-33.

Sayyar S, Abidin ZZ, Yunus R, Muhammad A. 2009. Extraction of oil from jatropha seeds optimation and kinetics. American Journal of Applied Science 6(7):1390-1395.

Senthil R dan Mohan K. 2015. Comparison of yield and fuel properties of thermal and catalytic Calophyllum inophyllum seed sheel pyrolytic oil. Journal of Chemical and Pharmaceutical Sciences 9:119-126.

Silitonga AS, Ong HC, Mahlia TMI, Masjuki HH, Chong WT. 2014. Biodiesel conversion from high FFA crude Jatropha curcas, Calophyllum inophyllum and Ceiba pentandra oil. Energy Procedia 61:480483.
Swern D. 1982. Bailey's Industrial Oil and Fat Products $4^{\text {th }}$ Edition. New York: John Wiley and Sons.

Syakir M dan Karmawati E. 2013. Tanaman Perkebunan Penghasil Bahan Bakar Nabati. Bogor (ID): Badan Litbang Kehutanan.

Tagora BPS, Sirait R, dan Iriany. 2012. Penentuan kondisi keseimbangan unit leaching pada produksi eugenol dari daun cengkeh. Jurnal Teknik Kimia USU 1(1):10-14.

Taifan WE, Ivander H, dan Gunawan S. 2013. Pemisahan dan pemurnian phythalic acid ester dari minyak nyamplung. Jurnal Teknik Pomits. 2(2):296-298.

Tempesta MS. 1993. Proanthocyanidin polymers having antiviral activity and methods of obtaining same. US Patent US005211944A.

Wibowo S, Syafii W, dan Pari G. 2010. Karakteristik arang aktif tempurung biji nyamplung (Calophyllum inophyllum). Jurnal Penelitian Hasil Hutan. 28(1):4354.

Yulviyanti M, Sari RM, dan Amaliah ER. 2014. Pengaruh perbandingan campuran pelarut n-heksan-etanol terhadap kandungan sitronelal hasil ekstraksi sereh wangi (Cymbopogon nardus). Jurnal Integrasi Proses. 5(1):8-14. 